\title{
ORGANOGENESIS AND LONG-TERM MICROPROPAGATION OF POLISH PEA CULTIVARS
}

\author{
TOMASZ PNIEWSKI ${ }^{1}$, JOANNA WACHOWIAK ${ }^{2}$, \\ JÓZEF KAPUSTA ${ }^{2}$, ANDRZEJ B. LEGOCKI ${ }^{2}$ \\ ${ }^{1}$ Institute of Plant Genetics, Polish Academy of Sciences \\ Strzeszyńska 34, 60-479 Poznań, Poland \\ e-mail: tpni@igr.poznan.pl \\ 2 Institute of Bioorganic Chemistry, Polish Academy of Sciences \\ Noskowskiego 12/14, 61-704 Poznań, Poland
}

(Received: May 5, 2003. Accepted: August 18, 2003)

\begin{abstract}
The complete protocol for regeneration and long-term micropropagation of several Polish cultivars of pea ( $P i$ sum sativum L.) has been elaborated. The shoots were the most likely regenerated via de novo organogenesis. The adventitious buds formed in callus derived from cotyledons tissue adjacent to the axillary meristems of immature embryos. All cultivars' calli regenerated several shoots per explant on the MS medium supplemented with B5 vitamins and $4.5 \mathrm{mgl}^{-1}$ of BAP, however some differences in regeneration capacity among cultivars were observed. The plantlets were subsequently micropropagated with slightly higher efficiency and preserving a good viability over the long-term culture on a medium containing $2.0 \mathrm{mgl}^{-1}$ than one with $4.5 \mathrm{mgl}^{-1}$ of BAP. The additional step of the pre-conditioning culture of multiplicated shoots on a medium with very low BAP concentration i.e. 0.02 $\mathrm{mgl}^{-1}$ was applied and appeared to be beneficial before rooting in vitro or grafting. The modified MS-derived medium with the half-strength of MS macroelements but with the full original dose of calcium and supplemented with B5 vitamins and $1.0 \mathrm{mgl}^{-1}$ of NAA was developed for effective rooting. The shoots were also sufficiently transferred into ex vitro conditions using grafting. The majority of the regenerated plants had adapted to in vivo conditions in a greenhouse and subsequently has set seeds. The presented protocol provides relatively efficient rate of de novo pea regeneration and would be useful for Agrobacterium-mediated transformation purposes.
\end{abstract}

KEY WORDS: pea, Pisum sativum, regeneration, organogenesis, micropropagation, rooting, grafting.

\section{INTRODUCTION}

Pea (Pisum sativum L.) is an important crop plant. It is cultured worldwide for seeds and as forage, sometimes also as a green fertilizer. The nutritive value of peas results from high protein content, likewise as other legumes. Besides, peas represent additional beneficial features. In contrast to most legumes, pea seeds contain very low or no anti-nutritive substances: alkaloids, protease inhibitors, hemagglutinins etc. and vegetative parts have a low percentage of fibers. Peas are commonly cultured in countries of moderate climate due to their relative resistance for harmful environment factors. Pea is one of legumes applied as a model for nitrogen fixation study and also as a plant of well-recognized genome quite often used for genetic rese-

\section{Abbreviations:}

2,4-D - 2, 4-dichlorofenoxyacetic acid; B5 - vitamins after Gamborg et al. (1968); BAP - 6-benzylaminopurine; KIN - kinetin; NAA - $\alpha$-naphtaleneacetic acid; MS - Murashige and Skoog medium (1962) arch (Casey and Davies 1993; Griga and Novák 1990; Jasińska and Kotecki 1993).

For the practical importance, methods of in vitro pea regeneration were the object of many studies. The in vitro regeneration is the prerequisite step of genetic transformation methods more and more often employed as a component of contemporary breeding programs. The following methods of in vitro cultures were applied to regenerate peas: direct regeneration via meristem cultures, organogenesis, somatic embryogenesis and protoplast cultures (for review: Davies and Mullineaux 1993; Griga and Novak 1990). To obtain transgenic peas, mainly organogenesis de novo (Grant et al. 1995; Polowick et al. 2000; Puonti-Kaerlas, 1990; Schroeder et al. 1993), but also meristem cultures (Bean et al. 1997; Davies et al. 1993; Nadolska-Orczyk and Orczyk 1999) have been successfully used. Unfortunately, the rate of pea transformation was low and varied considerably from a fraction of a percent up to several percent. For that reason, efficient regeneration and micropropagation protocol would be required to achieve reasonable transformation 
efficiency. If necessary, it should be also established suitable conditions of regeneration and transformation for cultivars of particular practical importance.

We present here the complete regeneration protocol for several Polish pea cultivars of diverse application: edible either dry or fresh pulses or used as forage. The protocol described here includes: organogenesis in the callus derived from immature embryos, following multiplication of obtained shoots and rooting or grafting. To elaborate this regeneration procedure, we exploited previous published data, which in a part were confirmed. We also developed some useful improvements. Moreover, the offered protocol seems to be appropriate for Agrobacterium-mediated transformation of peas.

\section{MATERIAL AND METHODS}

\section{Plant material}

The following Polish pea genotypes were used in the experiments:

- edible cultivars utilized for fresh (green) seed consumption: Pionier, Cud Kelwedonu, Delisa II, Konserwowy IHAR, Topaz,

- edible cultivars utilized for dry seed consumption: Agra, Kwestor,

- fodder cultivars: Grapis, Wiato.

\section{Media and culture conditions}

All media used in pea regeneration experiments consisted of MS salts (Murashige and Skoog 1962) and B5 vitamins (Gamborg et al. 1968). Most of the media were fullstrength MS. The media $1 / 2 \mathrm{PK}$ and PKA contained half amount of MS macroelements, except that, PKA was with a full dose of calcium. The media were supplemented with $3 \%(\mathrm{w} / \mathrm{v})$ sucrose and the following additions of plant growth regulators (Table 1 ).

The $\mathrm{pH}$ was adjusted to 5.7 prior to the addition of agar. Agar (Serva) was added to $0.7 \%(\mathrm{w} / \mathrm{v})$ in the media: P0, $\mathrm{P} 1, \mathrm{P} 2, \mathrm{P} 3, \mathrm{P} 4$ or $0.8 \%$ in the media: PK, $1 / 2 \mathrm{PK}$, PKA. Media were sterilized by autoclaving at $121^{\circ} \mathrm{C}$ for $20 \mathrm{mi}-$ nutes $(106 \mathrm{kPa})$.

Primary explants, calli, regenerated plantlets and rooting pea shoots were cultured in approximately 4000 lx of light intensity at $16 / 8 \mathrm{~h}$ light/dark photoperiod and at $24 / 18^{\circ} \mathrm{C}$ day/night temperature regime. Regenerated pea plants were transferred into soil mixed with perlit (in the ratio $1: 1)$ and they were grown in a greenhouse at $16 / 8 \mathrm{~h} \mathrm{li-}$ ght/dark photoperiod and at $22 / 16^{\circ} \mathrm{C}$ day/night temperature regime.

TABLE 1. The MS macroelements and plant growth regulators composition in regeneration media.

\begin{tabular}{lll}
\hline Medium & \multicolumn{2}{l}{ Constituents } \\
\hline & MS macroelements & Plant growth regulators $\left[\mathrm{mgl}^{-1}\right]$ \\
\hline P0 & full-strength MS & $0.2 \mathrm{KIN}, 1.02,4-\mathrm{D}$ \\
P1 &, & $2.0 \mathrm{BAP}, 2.0 \mathrm{NAA}$ \\
P2 &, & $4.5 \mathrm{BAP}, 0.02 \mathrm{NAA}$ \\
P3 &, & $2.0 \mathrm{BAP}$ \\
P4 &, & $0.02 \mathrm{BAP}$ \\
PK &, & $1.0 \mathrm{NAA}$ \\
$1 / 2 \mathrm{PK}$ & $1 / 2 \mathrm{MS}$ & $1.0 \mathrm{NAA}$ \\
PKA & $1 / 2 \mathrm{MS}$ except a full dose of $\mathrm{Ca}^{2+}$ & $1.0 \mathrm{NAA}$ \\
\hline
\end{tabular}

\section{In vitro culture initiation and regeneration}

The plant material used for primary explants preparation were green seeds, fully developed but just before drying. Pods with seeds at the appropriate stage were harvested from plants growing in the greenhouse in the conditions described above. Pods were surface-sterilized by immersing for 30 seconds in $70 \%$ ethanol followed by 20 minutes in $25 \%$ commercial chlorine bleach (Clorox) with $0.01 \%$ Tween 20 and finally rinsed 4-5 times with sterilized distilled water. The pods were then cut longitudinally with a scalpel and the seeds were released. The seed coats were removed and then the embryo roots and the distal parts of cotyledons were excised. Finally seeds were cut along longer axis into two halves and each half was divided again, so four explants were derived from one seed. The explant consisted of fragment of embryo axis, cotyledonary node and basal part of cotyledon adjacent to meristematic region (Fig. 1). Primary explants were transferred onto P0 medium and cultured 3 days in darkness at $24 / 18^{\circ} \mathrm{C}$ day/night temperature regime. The explants were transferred from P0 onto P1 medium and then were cultured 4-6 weeks to obtain callus. The shoots developing during 2-3 first weeks of culture were cut out and discarded as derived from remained pre-existing buds. At least 50 explants of each pea cultivar were used. Callus pieces were moved onto P2 medium inducing adventitious bud formation and further development. Calli were transferred onto fresh medium every 4-5 weeks. The developed plantlets were cut out from calli and moved for multiplication into jars containing P2 or P3 medium. Micropropagation studies were performed throughout at least 6 successive, six-week long subcultures. At least 40 plantlets were cultured in a separate multiplication passage. To micropropagate, multiplantlets were divided lengthways into smaller ones or separate shoots or these shoots were cut up into single or double nodes. Besides multiplication, plantlets were transferred onto $\mathrm{P} 4$ medium to promote shoot elongation. Fully developed shoots were then transferred onto rooting media: PK, 1/2PK and PKA or used for grafting experiments. Rooting and grafting studies were performed for at least 30 shoots. Rooted plants were transferred into pots with soil/perlit mixture and conditioned.

Besides rooting, shoots derived from the micropropagation subcultures were also used for grafting studies. Regenerated shoots were grafted onto their respective rootstocks of the same cultivars. The rootstocks were the two weekold seedlings prepared for grafting by cutting a V-shaped notch in the $1^{\text {st }}$ or $2^{\text {nd }}$ nodal region. Shoots developing from remaining axillary buds of rootstock at the beginning of healing were removed. Rooted or grafted plants were grown in the greenhouse until the seeds set.

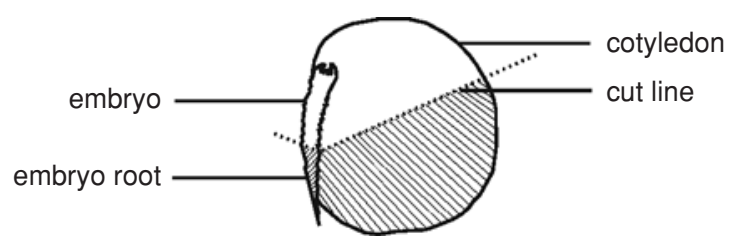

Fig. 1. The diagram of preparation of primary pea explants - immature embryo slices containing embryo axis and basal part of cotyledon (shaded parts - removed). 


\section{Estimation of regeneration efficiency}

The organogenesis efficiency was calculated by twofold values: as a percent of regenerating explants and as an average number of adventitious buds formed by a single explant. The parameters were estimated for all callus pieces derived from a separate primary explant kept together. Number of buds was calculated as an arithmetic mean together with standard deviation of population. The product of both parameters means entire organogenesis efficiency, i.e. the potential number of individual regenerants likely to obtain from 100 primary explants.

The micropropagation efficiency in a separate subculture was estimated as the multiplication ratio, as follows:

Multiplication ratio $=\frac{\text { geometric mean of new regenerants per a subculture }}{\text { geometric mean of parental regenerants per a subculture }}$

and geometric mean was derived from all passages using the formula:

$$
M_{G}=\sqrt[N]{\begin{array}{c}
i=N \\
i=1
\end{array}}
$$

$\mathrm{M}_{\mathrm{G}}$ - geometric mean

$\Pi \mathrm{X}_{\mathrm{i}}$ - product of newly formed or parental shoots

$\mathrm{N}$ - number of passages

The efficiency of rooting or grafting was estimated as the percent of successfully rooted or grafted shoots. Moreover, the percentage of regenerants adapted to in vivo conditions and the percent of regenerants setting seeds were estimated.

\section{RESULTS}

The primary pea explants derived from immature embryos (Fig. 1) cultured on P0 and following P1 media developed a firm-lumpy green callus during 4-6 weeks. Callus pieces were transferred onto the organogenesis-stimulating medium P2 and then formed adventitious buds and subsequent shoots (Fig. 2a, 2b). Studied genotypes differed distinctly in terms of the ability to organogenesis (Table 2). The highest percent (81-97\%) of regenerating explants has been noted for cultivars: Wiato, Agra and Kwestor, and middle values $(62-87 \%)$ were observed for: Konserwowy
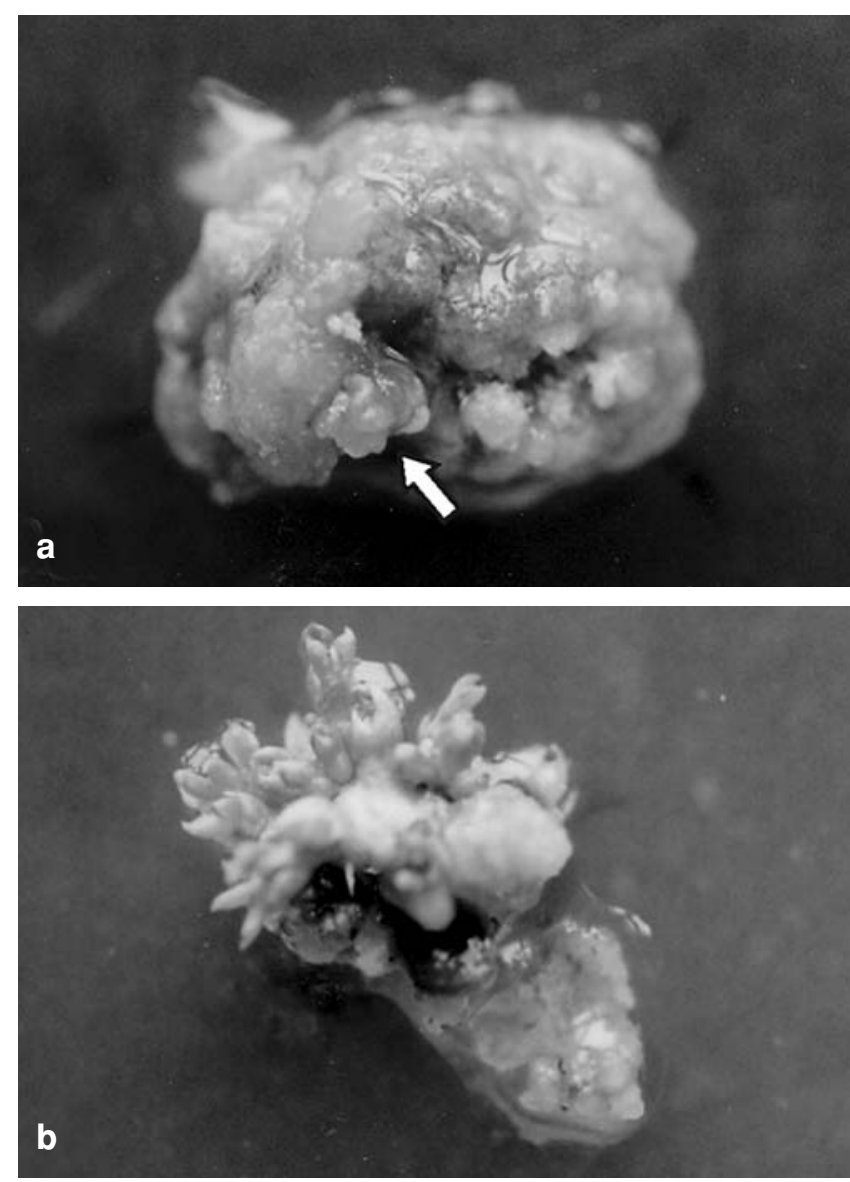

Fig. 2. Organogenesis of pea cv. Wiato: a) adventitious buds formed in callus tissue (one of them indicated by arrow); b) developed shoots

IHAR, Topaz and Delisa II (Table 2). However, the highest average number of buds formed by single explant (from 5.1 to 5.8) was characteristic for: Wiato, Grapis, Pionier, Konserwowy IHAR (Table 2). Combination, i.e. product of both parameters (percent of regenerating explants and average number of adventitious buds) reflected the potential number of individual regenerants possible to derive from 100 primary explants. Therefore, the highest regeneration potential characterized cultivars: Wiato and Konserwowy IHAR. Reasonable regeneration efficiency in the term of bud formation has also been noted for: Agra, Kwestor and Grapis (Table 2).

Regenerated plantlets were used for multiplication studies (Fig. 3, 4), which were performed for several passages on P2 or P3 media. The new shoots developed from apical

TABLE 2. Organogenesis efficiency of pea cultivars.

\begin{tabular}{lccc}
\hline & & \multicolumn{2}{c}{ Organogenesis parameter } \\
\cline { 2 - 4 } Cultivar & $\begin{array}{c}\text { Percent of regenerating } \\
\text { explants }\end{array}$ & $\begin{array}{c}\text { Average number } \\
\text { of adventitious buds per explant }\end{array}$ & $\begin{array}{c}\text { Potential number of regenerants per 100 primary explants } \\
=\text { entire organogenesis efficiency }\end{array}$ \\
\hline Agra & 96.8 & $4.1 \pm 1.8$ & $396.9 \pm 174.3$ \\
Kwestor & 81.0 & $4.3 \pm 1.0$ & $348.3 \pm 81.0$ \\
Grapis & 54.8 & $5.5 \pm 1.9$ & $301.4 \pm 104.1$ \\
Wiato & 96.1 & $5.8 \pm 2.3$ & $557.4 \pm 221.0$ \\
Pionier & 40.0 & $5.1 \pm 2.6$ & $204.0 \pm 104.0$ \\
Cud Kelwedonu & 44.4 & $4.9 \pm 2.1$ & $217.6 \pm 93.2$ \\
Delisa II & 61.5 & $4.5 \pm 1.9$ & $276.8 \pm 116.8$ \\
Konserwowy IHAR & 86.7 & $5.3 \pm 2.2$ & $459.5 \pm 190.8$ \\
Topaz & 75.0 & $3.4 \pm 1.9$ & $255.0 \pm 142.5$ \\
\hline
\end{tabular}


multiplication ratio

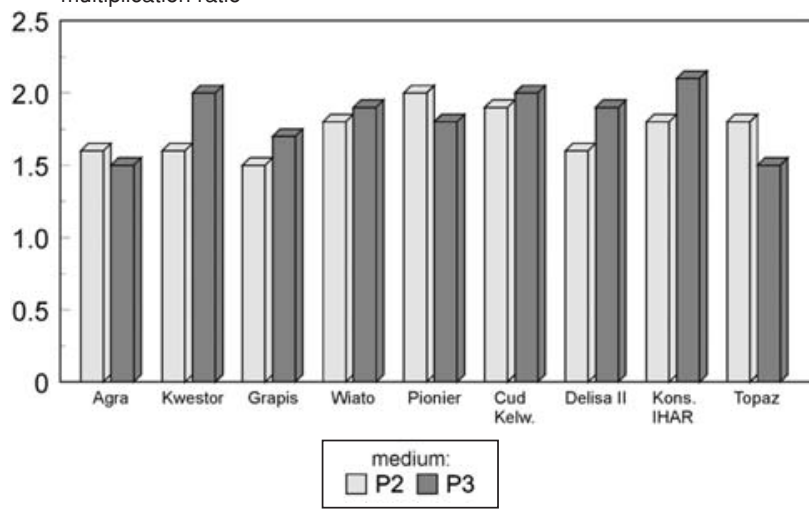

Fig. 3. Multiplication efficiency of pea regenerated plantlets on the media $\mathrm{P} 2$ and $\mathrm{P} 3$.

multiplication ratio $=\frac{\text { geometric mean of new regenerants per a subculture }}{\text { geometric mean of parental regenerants per a subculture }}$
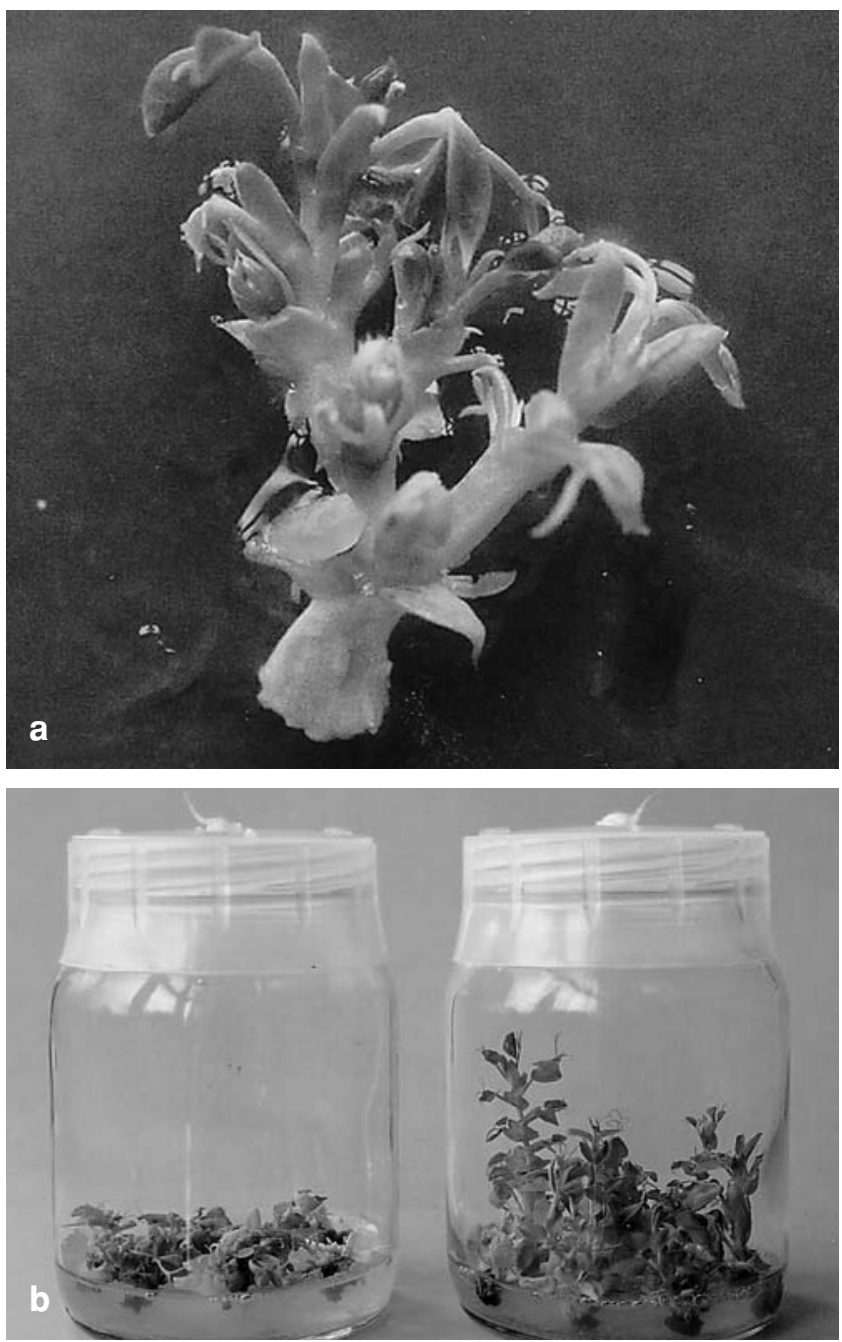

Fig. 4. Multiplication of plantlets: a) single multiplantlet; b) micropropagation culture of cv. Grapis: on P2 medium (left), on P3 medium (right).

or axillary buds (Fig. 4a). The multiplication efficiency was around 2.0 for most of the studied genotypes and slightly higher for P3 medium than P2. Any significant differences have not been observed among cultivars either (Fig. 3). However, P2 medium caused considerably more shoot dwarfing, vitrification and other deformations than P3 (Fig. 4b). The plantlets cultured on P3 medium have been still vigorous for two years or even longer (data not presented).
An additional step of culture on P4 medium was introduced between micropropagation and rooting or grafting. It has been observed that P4 medium induced elongation and somehow caused beneficial pre-conditioning effect for almost all cultured shoots (Fig. 5).

The rooting studies showed that, both pea genotype specificity and applied medium had affected the efficiency of this process (Fig. 6). The highest rooting ability (up to 68-83\%) was characterized by cultivars Wiato, Grapis, Konserwowy IHAR and Delisa II. Medium PKA induced roots formation for shoots of all used genotypes, however $1 / 2 \mathrm{PK}$ and especially PK medium had limited usefulness (Fig. 6, 7).

Grafting efficiency was also different among studied pea genotypes (Fig. 8). The highest percent (63-83\%) of healed shoots has been noted for: Kwestor, Topaz, Konserwowy IHAR and Agra.

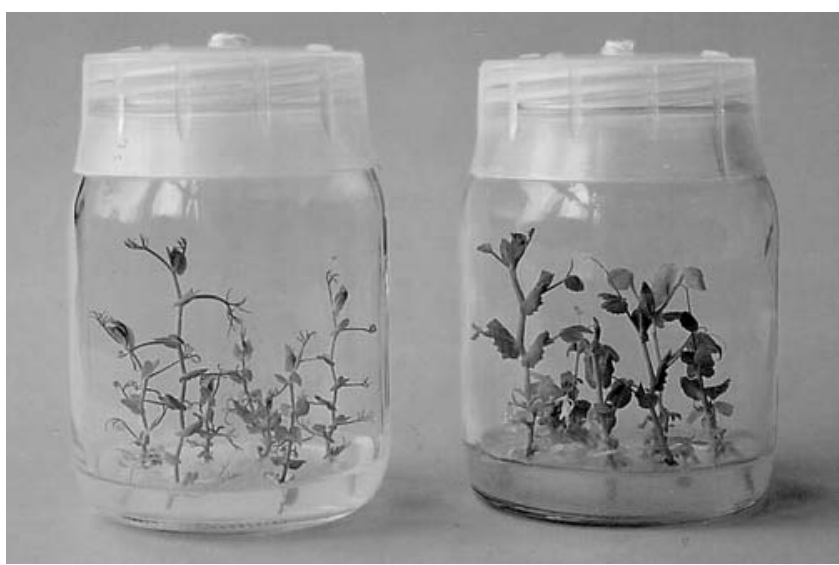

Fig. 5. Elongation of regenerated shoots on P4 medium: cv. Agra (left), cv. Kwestor (right).

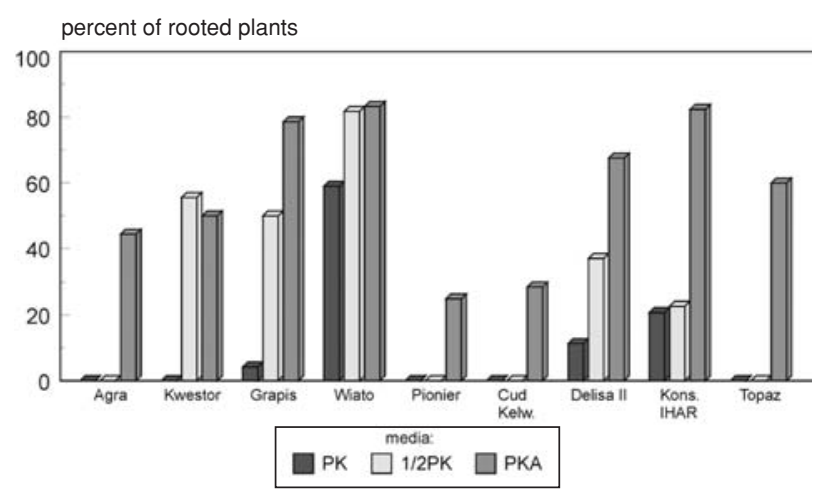

Fig. 6. Rooting efficiency of pea micropropagated shoots on the media: $\mathrm{PK}, 1 / 2 \mathrm{PK}$ and PKA.

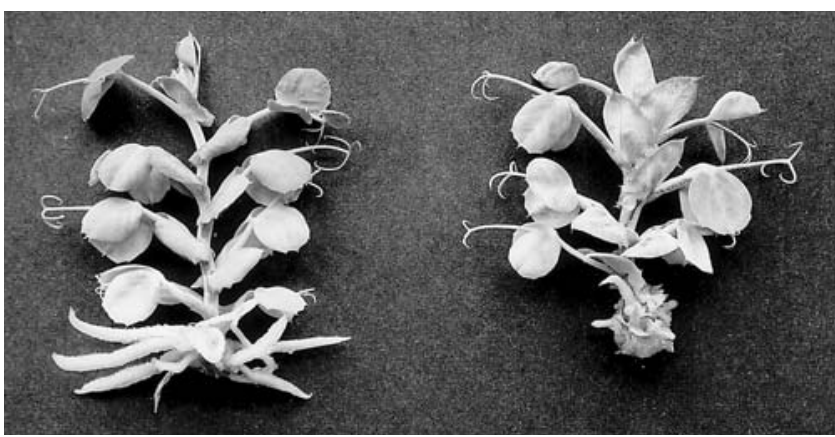

Fig. 7. Rooting of shoots of cv. Wiato: on PKA medium (left), on PK medium (right). 


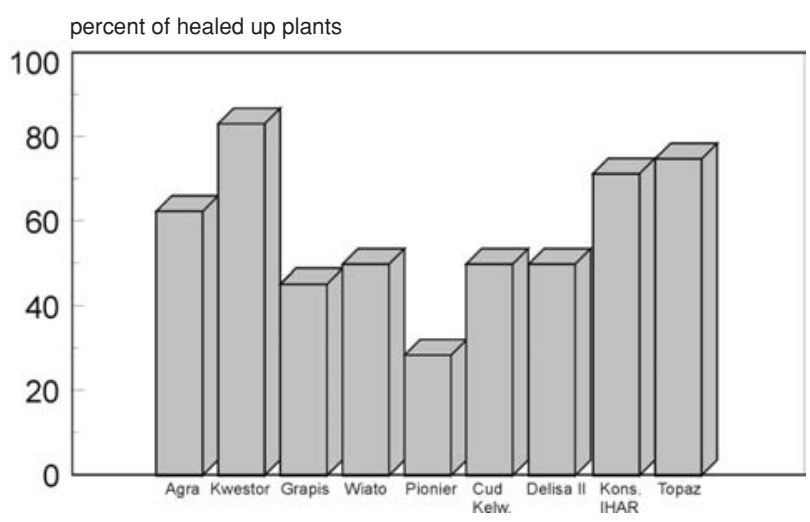

Fig. 8. Healing efficiency of regenerated in vitro pea shoots grafted on in vivo rootstocks.

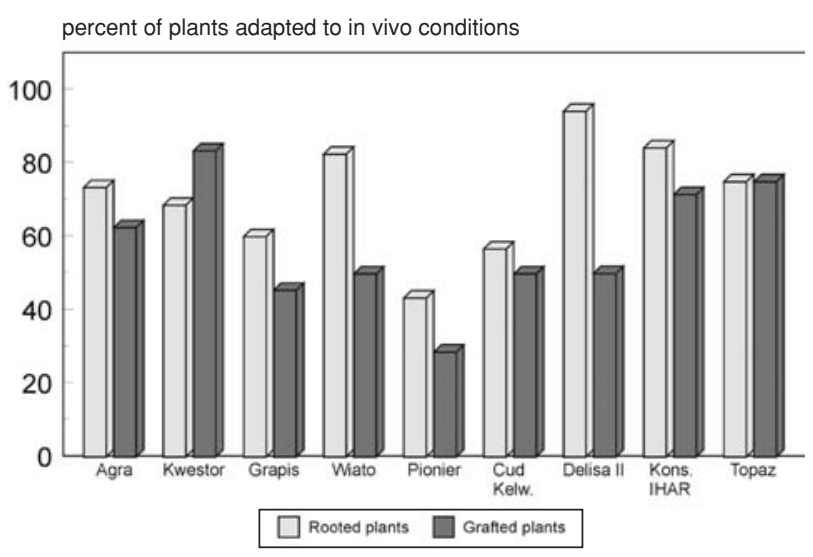

Fig. 9. Successful adaptation of rooted or grafted plants for ex vitro conditions.

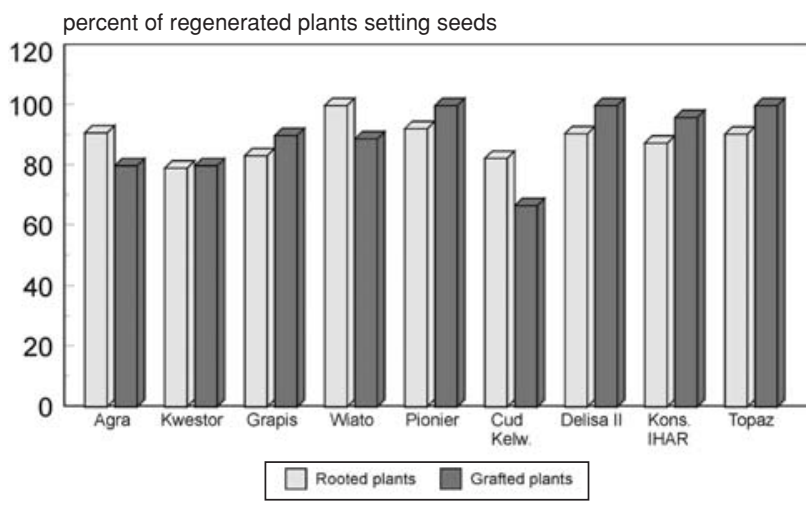

Fig. 10. Percent of rooted or grafted plants setting seeds.

Most of rooted or grafted plants were able to adapt to ex vitro conditions (Fig. 9). The majority of adapted plants formed seeds (Fig. 10, 11). The number of set pods and seeds was not high - usually a few per single plant. However, progeny plants were more vigorous and fertile (data not included).

\section{DISCUSSION}

The aim of our studies was to develop a protocol of pea regeneration through de novo organogenesis and applicable for transformation. We have chosen nine Polish pea culti-

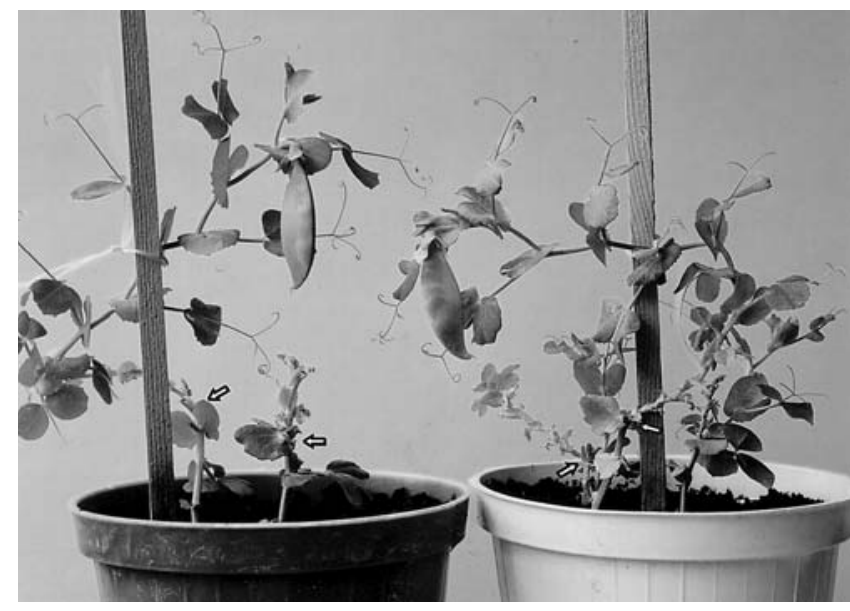

Fig. 11. Plants setting pods after grafting and adaptation for in vivo conditions: cv. Delisa II (left), cv. Konserwowy IHAR (right); arrows indicate grafting sites.

vars of different utilization type and botanic features to select a genotype characterizing a high regeneration potential. We have used immature embryos as primary explants, according to their high regeneration potential showed by other authors (Grant et al. 1995; Kosturkova et al. 1997; Nadolska-Orczyk et al. 1994; Natali and Cavallini 1987; Özcan et al. 1992; Schroeder et al. 1993; Tétu et al. 1990). Both embryo axis (Kosturkova et al. 1997; Natali and Cavallini 1987; Schroeder et al. 1993) and the nodal part of cotyledons (Grant et al. 1995; Nadolska-Orczyk et al. 1994; Özcan et al. 1992) were used as starting materials. However, in preliminary experiments, we observed that separated embryo axes were weak in the in vitro culture and died soon. On the other hand, isolated cotyledons formed callus but only a few buds. Concluding, we applied a new type of explant consisting both the embryo axis and part of cotyledon adjacent to meristematic region (Fig. 5), which was both vigorous, formed callus abundantly and developed adventitious buds. Efficient callus formation was stimulated for all studied cultivars on media P0 and P1. The media were supplemented, respectively, with KIN and 2,4D or BAP and NAA, following to other authors (Hussey and Gunn 1984; Kosturkova et al. 1997; Natali and Cavallini 1987; Schroeder et al. 1993).

The organogenesis was induced on the medium containing $4.5 \mathrm{mgl}^{-1}$ of BAP and $0.02 \mathrm{mgl}^{-1}$ of NAA. High cytokinin and very low auxin content seemed to be essential for initiation of morphogenesis in pea callus, as previously observed (Hussey and Gunn 1984; Kosturkova et al. 1997; Malmberg 1979; Mroginski and Kartha 1981; Natali and Cavallini 1987; Özcan et al. 1992; Rubluo et al. 1984; Tétu et al. 1990). Depending on a cultivar, percent of explantderived calli forming buds varied from 40 to $96 \%$ (Table 2). These values are approximately similar to earlier reports (Hussey and Gunn 1984; Kosturkova et al. 1997; Natali and Cavallini 1987; Özcan et al. 1992; Tétu et al. 1990). Another parameter of organogenesis efficiency, the average number of buds formed by single explant, ranged from 3.4 to 5.8 (Table 2), like in some papers (NadolskaOrczyk et al. 1994; Nauerby et al. 1991; Özcan et al. 1992). The observed results were sometimes incoherent, the percent of regenerating explants was high, but the number of formed buds was relatively low or the vice versa. In order to express the entire organogenesis efficiency we 
combined both regeneration parameters as a product of them. The highest regeneration ability characterized cultivars Wiato, Agra, Kwestor and Konserwowy IHAR which were potentially able to form around 400 or more new shoots from calli derived from 100 immature embryos (Table 2), within 3 to 4 months. Our data confirmed a fact of significant differences in organogenesis capacity among pea genotypes (Malmberg 1979; Nadolska-Orczyk et al. 1994; Natali and Cavallini 1987; Nauerby et al. 1991).

Micropropagation could be an integral phase of regeneration, which allows the multiply the number of regenerants, for example of individual transgenic shoots. Multiplication of formed shoots occurred through axillary or apical bud development (Fig. 4a). Micropropagation studies were carried out on media supplemented with $4.5 \mathrm{mgl}^{-1}$ or $2.0 \mathrm{mgl}^{-1}$ of BAP. The multiplication ratio based on geometric mean was applied to estimate a micropropagation efficiency (see Materials and methods). That parameter appeared to be more feasible to characterize process running through successive generations or cycles. We did not observe significant differences in multiplication ability among particular pea genotypes. Multiplication ratios were slightly higher on a medium containing $2.0 \mathrm{mgl}^{-1}$ of BAP than on a medium with $4.5 \mathrm{mgl}^{-1}$ of cytokinin (Fig. 9). The obtained micropropagation results were not so satisfactory as other authors' data (Franklin et al. 2000; Griga et al. 1986; Hussey and Gunn 1984; Jackson and Hobbs 1990; Mallick and Rashid 1989), the average multiplication ratio was around 2.0 in comparison to 6.0-30.0. Presumably, lower micropropagation rate could be attributed to the fact that shoots obtained from callus were somewhat less vigorous despite shoots grown from original plumules. Additionally, we observed that high BAP dose was disadvantageous for a long-term micropropagation. Newly formed shoots were dwarfed, vitrificated (Fig. 4b) and incapable to form roots. Our observations suggest application of initial high cytokinin doses for organogenesis induction but subsequently lower concentrations for micropropagation, as it was postulated earlier (Jackson and Hobbs 1990). We could still obtain new shoots in a good condition after two years of micropropagation.

Regenerated shoots can be transferred into ex vitro conditions by two manners, rooting or grafting. In the most of reported protocols, regenerated shoots were rooted directly without any pre-conditioning phase (Griga et al. 1986; Hussey and Gunn 1984; Kubaláková et al. 1988; NadolskaOrczyk et al. 1994; Natali and Cavallini 1987; Nauerby et al. 1991; Nielsen et al. 1991; Özcan et al. 1992). Our results did not confirm such possibility because the most of multiplicated shoots was dying after transfer onto rooting media. We inferred that shoot mortality was caused by the stress of extreme change of phytohormones provided in the media, from a relatively high dose of cytokinin (BAP) to auxin (NAA). We introduced the additional step of culturing on the medium containing a very low dose of BAP $\left(0.02 \mathrm{mgl}^{-1}\right)$ to make the pass from micropropagation to rooting more moderate. Additionally, due to low dose of cytokinin, the shoots became longer and more natural in appearance (Fig. 5). The elongation and the pre-conditioning were beneficial before either rooting or grafting.

Elongated shoots were transferred onto three rooting media varying in salt concentrations, but containing the same dose of NAA (1.0 mgl-1) following several authors (Cardi et al. 1991, Griga et al. 1986, Kubaláková et al. 1988; Nielsen et al. 1991). In opposition to some data (Griga et al. 1986), our observations showed that the full-strength MS medium was generally inappropriate to induce rooting (Fig. 6, 7). The half-strength MS medium was more effective, as in the earlier reports (Cardi et al. 1991; Hussey and Gunn 1984; Kubaláková et al. 1988; Özcan et al. 1992), but also not sufficient. Plants rooted on this medium were in poor condition and they adapted for ex vitro conditions with difficulty. The most efficient the rooting appeared in PKA medium, containing a half dose of MS macroelements, but with full original concentration of calcium (Fig. $6,7)$. We composed this medium basing on fact, that peas are sensitive to the deficiency of that component (Jasińska and Kotecki 1993). The PKA medium stimulated root formation for all pea cultivars tested and the rates of rooted plants were also higher than on the other media (Fig. 6). As other authors (Cardi et al. 1991; Kubaláková et al. 1988; Nadolska-Orczyk et al. 1994; Nauerby et al. 1991), we observed genotype-dependent capability to rhizogenesis. Similarly to some earlier results (Cardi et al. 1991; Kubaláková et al. 1988; Nauerby et al. 1991; Özcan et al. 1992), a relatively big part (25-80\%) of shoots formed roots and maintained rooting ability during a long-term culture. In our experiments the highest root formation rate was found in cv. Wiato, Grapis, Delisa II and Konserwowy IHAR.

For genotypes characterizing low rooting ability, grafting can be used as an alternative method of transferring shoots into in vivo conditions. Occasionally, this approach was also used as the main method for ex vitro transferring and adaptation (Bean et al. 1997; Ezhova et al. 1985). Grafting efficiency of in vitro cultured shoots ranged from 30 to 95\% (Fig. 8) but it was high enough for transfer of regenerants into in vivo conditions. For cultivars Agra, Kwestor, Pionier, Cud Kelwedonu and Topaz, it was even higher than rooting (Fig. 6, 8).

In our experiments, in vivo adaptation rate of rooted plants was generally higher than grafted ones (Fig. 9). However, we observed relatively high percent of fertile plants, either rooted or grafted (Fig. 10).

Summarizing our experiments from all culture stages, the highest regeneration potential characterized $\mathrm{cv}$. Wiato and Konserwowy IHAR, and these results suggest using them for transformation studies. Reasonable regeneration ability has also been observed for other cultivars tested except Pionier and Cud Kelwedonu.

In conclusion, we worked out the regeneration protocol through effective de novo organogenesis for certain Polish pea cultivars. Shoots regenerated from immature embryos can be sufficiently micropropagated and subsequently efficiently rooted in vitro or grafted after pre-conditioning. Thus far, transgenic pea plants were mainly obtained after inoculation of immature embryos with Agrobacterium strains and subsequent organogenesis in callus (Grant et al. 1995; Polowick et al. 2000; Puonti-Kaerlas 1990; Schroeder et al. 1993). Presented regeneration protocol seems to be useful and easily adaptable for pea transformation procedures. 


\section{ACKNOWLEDGMENTS}

This work was supported by grant 6 PO4B 012016 of Polish State Committee for Scientific Research.

\section{LITERATURE CITED}

BEAN S.J., GOODING P.S., MULLINEAUX P.M., DAVIES D.R. 1997. A simple system for pea transformation. Plant Cell Rep. 16: 513-519.

CARDI T., ADAMO F., FILIPPONE E. 1991. In vitro rooting of differentiated shoots in various genotypes of pea. Journal of Genetics and Breeding 45: 67-69.

CASEY R., DAVIES D.R. 1993. Peas: Genetics, Molecular Biology and Biotechnology. CAB International, Wallingford, UK.

DAVIES D.R., HAMILTON J., MULLINEAUX P.M. 1993. Transformation of peas. Plant Cell Rep. 12: 180-183.

DAVIES D.R., MULLINEAUX P.M. 1993. Tissue culture and transformation. In: Casey R. and Davies D.R. (Eds.) Peas: Genetics, Molecular Biology and Biotechnology, CAB International, Wallingford, UK, pp. 291-301.

EZHOVA T.A., BAGROVA A.M., GOSTIMSKIJ S.A. 1985. Pobiegoobrazovanije v kallusah iz vierkhushek stieblej, epikotilej, miezhdouzlij i list'yev razlitchnykh gienotipov gorokha. Fiziol. Rast. 32: 513-520 (in Russian and English summary).

FRANKLIN G., PIUS P.K., IGNACIMUTHU S. 2000. Factors affecting in vitro flowering and fruiting of green pea (Pisum sativum L.). Euphytica 115: 65-73.

GAMBORG O.L., MILLER R.A., OJIMA K. 1968. Nutrient requirements for suspension cultures of soybean root cells. Exp. Cell Res. 50: 151-158.

GRANT J.E., COOPER P.A., McARA A.E., FREW T.J. 1995. Transformation of peas (Pisum sativum L.) using immature cotyledons. Plant Cell Rep. 15: 254-258.

GRIGA M., TEJKLOVÁ E., NOVÁK F.J., KUBALÁKOVÁ M. 1986. In vitro clonal propagation of Pisum sativum L. Plant Cell, Tissue and Organ Culture 6: 95-104.

GRIGA M., NOVAK F.J. 1990. Pea (Pisum sativum L.). In: Bajaj Y.P.S. (ed.) Biotechnology in Agriculture and Forestry 10. Legumes and Oilseed Crops I, Springer-Verlag, Berlin, pp. II.165-II.1-94.

HUSSEY G., GUNN H.V. 1984. Plant production in pea (Pisum sativum L. cvs. Puget and Upton) from long-term callus with superficial meristems. Plant Science Letters 37: 143-148.

JACKSON J.A., HOBBS S.L.A. 1990. Rapid multiple shoot production from cotyledonary node explants of pea (Pisum sativum L.). In vitro Cellular and Developmental Biology 26: 835-838.

JASIŃSKA Z., KOTECKI A. 1993. Groch. In: Rośliny strączkowe. Wydawnictwo Naukowe PWN, Warszawa, pp. III-61-III89 (in Polish).

KOSTURKOVA G., MEHANDJIEV A., DOBREVA I., TZVETKOVA V. 1997. Regeneration systems from immature embryos of Bulgarian pea genotypes. Plant Cell, Tissue and Organ Culture 48: 139-142.
KUBALÁKOVÁ M., TEJKLOVÁ E., GRIGA M. 1988. Some factors affecting root formation on in vitro regenerated pea shoots. Biologia Plantarum 30: 179-184.

MALLICK M.A., RASHID A. 1989. Induction of multiple-shoots from cotyledonary node of grain legumes, pea and lentil. Biologia Plantarum 31: 230-232.

MALMBERG R.L. 1979. Regeneration of whole plants from callus culture of diverse genetic lines of Pisum sativum L. Planta 146: 243-244.

MROGINSKI L.A., KARTHA K.K. 1981. Regeneration of pea (Pisum sativum L. cv. Century) plants by in vitro culture of immature leaflets. Plant Cell Rep. 1: 64-66.

MURASHIGE T., SKOOG F. 1962. A revised medium for rapid growth and bioassays with tobacco tissue cultures. Physiol. Plantarum 15: 473-479.

NADOLSKA-ORCZYK A., MIŁKOWSKA L., ORCZYK W. 1994. Two ways of plant regeneration from immature cotyledons of pea. Acta Soc. Bot. Pol. 63: 153-157.

NADOLSKA-ORCZYK A., ORCZYK W. 1999. Study of the factors influencing Agrobacterium-mediated transformation of pea (Pisum sativum L.) Molecular Breeding 0: 1-10.

NATALI L., CAVALLINI A. 1987. Regeneration of pea (Pisum sativum $\mathrm{L}$.) plantlets by in vitro culture of immature embryos. Plant Breeding 99: 172-176.

NAUERBY B., MADSEN M., CHRISTIANSEN J., WYNDAELE R. 1991. A rapid and efficient regeneration system for pea (Pisum sativum), suitable for transformation. Plant Cell Rep. 9: 676-679.

NIELSEN S.V.S., POULSEN G.B., LARSEN M.E. 1991. Regeneration of shoots from pea (Pisum sativum) hypocotyl explants. Physiol. Plantarum 82: 99-102.

ÖZCAN S., BARGHCHI M., FIREK S., DRAPER J. 1992. High frequency adventitious shoot regeneration from immature cotyledons of pea (Pisum sativum L.). Plant Cell Rep. 11: 44-47.

POLOWICK P.L., QUANDT J., MAHON J.D. 2000. The ability of pea transformation technology to transfer genes into peas adapted to western Canadian growing conditions. Plant Science 153: 161-170.

PUONTI-KAERLAS J., ERIKSSON T., ENGSTRÖM P. 1990. Production of transgenic pea (Pisum sativum L.) plants by Agrobacterium tumefaciens-mediated gene transfer. Theor. and Appl. Genet. 80: 246-252.

RUBLUO A., KARTHA K.K., MROGINSKI L.A., DYCK J. 1984. Plant regeneration from pea leaflets cultured in vitro and genetic stability of regenerants. J. Plant Physiol. 117: 119-130.

SCHROEDER H.E., SCHOTZ A.H., WARDLEY-RICHARDSON T., SPENCER D., HIGGINS T.J.V. 1993. Transformation and regeneration of two cultivars of pea (Pisum sativum L.). Plant Physiol. 101: 751-757.

TÉTU T., SANGWAN R.S., SANGWAN-NORREEL B.S. 1990. Direct somatic embryogenesis and organogenesis in cultured immature zygotic embryos of Pisum sativum L. Plant Physiol. 137: 102-109. 


\section{ORGANOGENEZA ORAZ MIKROROZMNAŻANIE POLSKICH ODMIAN GROCHU}

\section{STRZESZCZENIE}

Opracowano kompletny protokół regeneracji oraz mikrorozmnażania dla kilku polskich odmian grochu (Pisum sativum L.). Zregenerowane pędy rozwinęły się najprawdopodobniej na drodze organogenezy de novo. Pąki przybyszowe tworzyły się w kalusie pochodzącym z tkanki liścieni przylegającej do merystemów kątowych niedojrzałych zarodków. Pędy, średnio po kilka na wyjściowy eksplantat, zregenerowano w kalusie wszystkich badanych odmian na pożywce MS uzupełnionej witaminami B5 oraz $4,5 \mathrm{mgl}^{-1} \mathrm{BAP}$. Zaobserwowano jednak pewne różnice w zdolności do regeneracji pomiędzy poszczególnymi odmianami. Uzyskane pędy były następnie mikrorozmnażane. Nieco większą wydajność wraz z zachowaniem żywotności pędów w trakcie długotrwałej kultury zanotowano na pożywce zawierającej $2,0 \mathrm{mgl}^{-1} \mathrm{BAP}$ w porównaniu z $4,5 \mathrm{mgl}^{-1}$ tej cytokininy. Zastosowano dodatkowy etap kultury pędów na pożywce o niskiej zawartości BAP tj. 0,02 $\mathrm{mgl}^{-1} \mathrm{z}$ uwagi na jego korzystny wpływ przed ukorzenianiem lub szczepieniem. Optymalną pożywką ukorzeniającą była zmodyfikowana pożywka MS, zawierająca pełną oryginalną dawkę $\mathrm{Ca}$, natomiast połowę ilości pozostałych makroelementów oraz uzupełniona witaminami B5 oraz 1,0 $\mathrm{mgl}^{-1}$ NAA. Pędy adaptowały się także wydajnie do warunków in vivo przez szczepienie. Większość zregenerowanych roślin zaadaptowała się do warunków szklarniowych i zawiązała nasiona. Niniejszy protokół przedstawia stosunkowo wydajną metodę regeneracji grochu de novo i może być użyteczny dla celów transformacji za pomocą Agrobacterium sp.

SŁOWA KLUCZOWE: groch, Pisum sativum, regeneracja, organogeneza, mikrorozmnażanie, ukorzenianie, szczepienie. 